Notes and Comments

\title{
First record of Kelleridae in Brazilian waters. A geographical range expansion and a new Kelleria (Gurney, 1927) morphotype
}

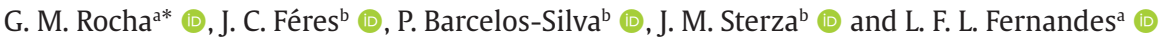 \\ âniversidade Federal do Espírito Santo - UFES, Departamento de Oceanografia e Ecologia, Vitória, ES, Brasil \\ 'Ethica Ambiental Serviços e Consultoria Ltda., Vila Velha, ES, Brasil
}

Kelleridae is a copepod family found in all continents, mainly in tropical latitudes (Oomoto and Ueda, 2016) and is composed by 21 valid species, all in the genus Kelleria (Walter and Boxshall, 2021). It has a coastal epibenthic habit, with occasional presence in the plankton (Gurney, 1927; Gómez, 2006; Oomoto and Ueda, 2016; Walter and Boxshall, 2021). Oomoto and Ueda (2016, p. 47) noted that "Most species are probably endemic to their type localities. [...] about half of these species are described together with other congeners from the same sampling site or region".

Açu and Iquipari lagoons (4059'00"W; $21^{\circ} 55^{\circ} 04^{\circ} \mathrm{S}$ and $41^{\circ} 01^{\prime} 27^{\prime \prime} \mathrm{W} ; 21^{\circ} 44^{\prime} 17^{\prime \prime}$ S respectively), sampled in this study, are located in the São João da Barra district, northern coast of the Rio de Janeiro State, Brazil. They have a narrow sand bar from the sea, which does not prevent the salinity to intrude its continental waters and Açu can become hypersaline during the dry season (Chagas and Suzuki, 2005; Rocha et al., 2019). Both lagoons are shallow (less than $1.5 \mathrm{~m}$ ) with sandy sediment and seasonal benthic macroalgae near the sand bar and aquatic macrophytes on the inner area (Suzuki et al., 2002; Chagas and Suzuki, 2005; Monteiro and Gomes-Junior, 2005).

Samples were taken 330 and 1,500 meters away from shore at the Açu lagoon and 150 meters at the Iquipari lagoon by filtering $200 \mathrm{~L}$ of surface water with a graduated bucket through a $60 \mu \mathrm{m}$ mesh plankton net and preserved in $4 \%$ buffered formalin. Aliquots were analyzed using stereoscopic and optical microscopes until efficiency rate of 0.8 (Pappas and Stoermer, 1996; Cardoso and Marques, 2004) was achieved. Stacks of images at different focal distances, produced by a digital camera attached to a Biofocus Blue-1000 B-I-L-BI optical microscope, were assembled using Adobe Photoshop ${ }^{\circledR}$ and used as templates in Adobe Illustrator ${ }^{\circledR}$ to create vector graphic illustrations.

Results showed the first record of Kelleridae in Brazil. General view and taxonomic features of the collected specimens are shown in Figure 1. We found two different species of Kelleria. One is identified to Kelleria reducta (Gómez, 2006) and the other has some unique morphological features, indicating the possibility of an undescribed Kelleria species.

Our first record of Kelleria reducta in Brazil was at the Açu lagoon in November of 2016 (39.0 salinity), and the other Kelleria species (Kelleria sp.1) was first registered at Iquipari lagoon, in January 2017 (2.4 salinity) (Table 1). Since then, K. reducta was found again in April and October of 2019 and March of 2021 at the Açu lagoon and Kelleria sp.1 in February of 2020, also at the Açu lagoon, indicating a stable and reproductively viable population in the region with the presence of juvenile forms.

Kelleria reducta was described on an estuarine system at Sinaloa, Mexico (Gómez, 2006) as the first Kelleria species found in the American continent. After that, K. reducta was found in 2012 at a coastal lagoon and in the littoral zone in Colombia (Suárez-Morales and Fuentes-Reinés, 2015; Fuentes-Reinés and Suárez-Morales, 2017).

Female specimens of Kelleria reducta found in our study have two mediobasal teeth of mandibular blade, which are much larger than the others (Figure 1B), and maxillipedal basis with one long distal and on shorter proximal spines (Figure 1C), which are the main diagnostic characters for the species (Gómez, 2006). Regarding the caudal rami length/width ratio, our individuals have about 2.0 (Figure 1A), same as the Colombian specimen (Suárez-Morales and Fuentes-Reinés, 2015), while Gómez (2006) described a 3.0 ratio. The body size ranged from 1.00 to $1.05 \mathrm{~mm}(\mathrm{n}=5)$, which is within the range found by Gómez (2006). Leg 5 has a serrate margin (Figure 1D), which is also a characteristic feature of the species.

Specimens of Kelleria sp.1 is similar to K. regalis (Gurney, 1927) by having a bifid proximal spine on the second segment of the maxilliped and a pointed medial process at the first segment (Gurney, 1927) (Figure 1F). However, our individuals also have distinct features from what was described in Gurney (1927) and in Humes and Ho (1969) (Table 2$)$ such as: 1$)$ shorter body length $(0.9 \mathrm{~mm})$ [between 1.25 and $1.45 \mathrm{~mm}$ in K. regalis]; 2) prosome shape in dorsal view (Figure 1E) [wider then $K$. regalis]; 3 ) relative size of distal spines on the maxilla (Figure 1F); 4) 15 spinules on the maxilla proximal spine (Figure 1G) [12 spinules in K. regalis] and 5) serrate margin around leg 5 (Figure $1 \mathrm{H}$ ) [absent in $K$. regalis].

Kelleria is considered epibenthic and their abundance in the plankton would greatly depend on water turbulence and life history of the species. We found over $11 \%$ relative abundance of the genus among the zooplankton community

*e-mail: gusmrocha@uol.com.br

Received: August 27, 2021 - Accepted: December 10, 2021 


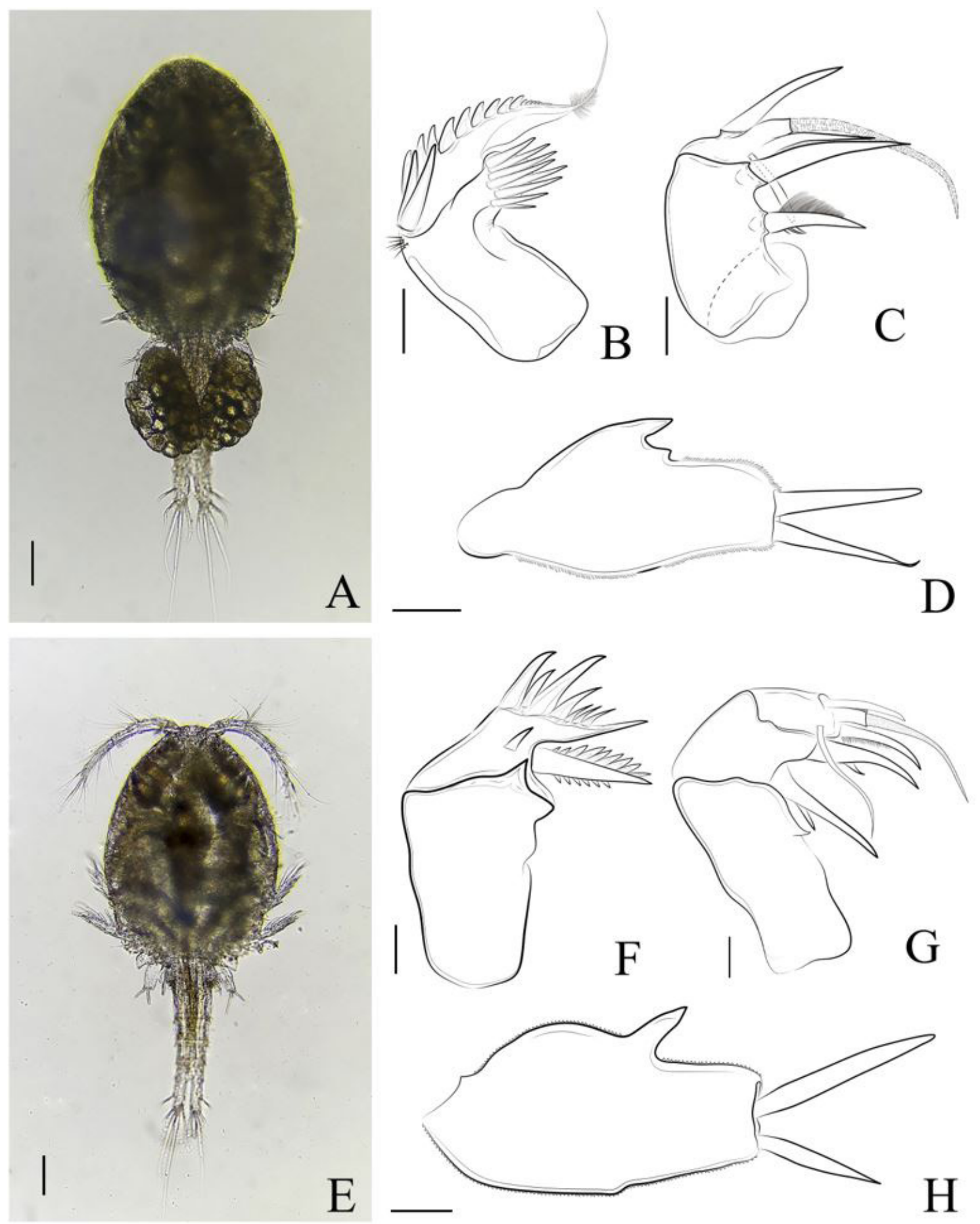

Figure 1. General view and taxonomic features. Kelleria reducta: adult female(A). mandible (B), maxilliped(C) and leg 5 (D). Kelleria sp1: adult female $(E)$, maxilla $(F)$, maxilliped $(G)$, leg $5(H)$. Scale bar: adult individuals $-90 \mu \mathrm{m}$. Appendages $-22.5 \mu \mathrm{m}$.

at the Açu lagoon in December of 2017, suggesting a planktonic life stage for copepodite. Because we repeatedly found juvenile forms of Kelleria at both lagoons, it is likely that populations of both species are well established in the region, reinforcing Kelleria as a widespread genus of
Copepoda, as is well known since its first occurrence in the American continent (Gómez, 2006).

The present paper expands $K$. reducta southern range distribution from Colombia to Brazil which appears to be an endemic species from the American continent, as well 
Table 1. Density of Kelleria species found at the Açu and Iquipari lagoons from 2016 to 2021.

\begin{tabular}{ccccc}
\hline Month/Year & Lagoon & Kelleria sp.1 & K. reducta & Kelleria spp (juvenile) \\
\hline November/16 & Açu & - & $37 \mathrm{ind} / \mathrm{m}^{3}$ & - \\
January/17 & Iquipari & $250 \mathrm{ind} / \mathrm{m}^{3}$ & - & - \\
December/17 & Açu & - & - & $34,500 \mathrm{ind} / \mathrm{m}^{3}$ \\
April/19 & Açu & - & $12 \mathrm{ind} / \mathrm{m}^{3}$ & - \\
October/19 & Açu & - & $24 \mathrm{ind} / \mathrm{m}^{3}$ & - \\
February/20 & Açu & $750 \mathrm{ind} / \mathrm{m}^{3}$ & - & $375 \mathrm{ind} / \mathrm{m}^{3}$ \\
March/21 & Açu & - & $25 \mathrm{ind} / \mathrm{m}^{3}$ & - \\
\hline
\end{tabular}

“-” absence of taxa

Table 2. Morphological comparison of Kelleria sp1 females in the present study with K. regalis previously described. Table adapted from Oomoto and Ueda (2016).

\begin{tabular}{|c|c|c|c|}
\hline \multirow[b]{2}{*}{ Reference and Locality } & \multicolumn{2}{|c|}{ Kelleria regalis } & \multirow{2}{*}{$\begin{array}{c}\text { Kelleria sp.1 } \\
\text { present study Rocha et al. } \\
(2024)\end{array}$} \\
\hline & $\begin{array}{l}\text { sensu stricto Gurney (1927), } \\
\text { Egypt }\end{array}$ & sensu Humes \& Ho (1969) & \\
\hline & Suez Canal, Egypt & Nosy Bé, Madagascar & São João da Barra, Brazil \\
\hline Body length & $1.45 \mathrm{~mm}$ & $1.25-1.37 \mathrm{~mm}$ & $0.9 \mathrm{~mm}$ \\
\hline Caudal ramus L/W & 3 & 2.3 & 3 \\
\hline \multicolumn{4}{|l|}{ Maxilla } \\
\hline Distal spines & ${ }^{* *} 7\left(4^{\text {th }}\right.$ is less than half of $\left.3^{\text {th }}\right)$ & ${ }^{* *} 8\left(4^{\text {th }}\right.$ is less than half of $\left.3^{\text {th }}\right)$ & $7\left(4^{\text {th }}\right.$ is more than half of $\left.3^{\text {th }}\right)$ \\
\hline Spinules on proximal spine & $\begin{array}{l}\text { ** top side with } 8 \text { spinules } \\
\text { and basal side with } 4\end{array}$ & ${ }^{* *}$ both sides with 6 spinules & $\begin{array}{c}\text { Top side with } 9 \text { spinules and } \\
\text { basal side with } 6\end{array}$ \\
\hline $\begin{array}{l}\text { Pointed process at top of } \\
\text { basal joint }\end{array}$ & **absent & present & present \\
\hline Center setae at second joint & absent & present & present \\
\hline \multicolumn{4}{|l|}{ Maxilliped } \\
\hline $\begin{array}{l}\text { Second segment, proximal } \\
\text { spine bifid* }\end{array}$ & present & present & present \\
\hline $\begin{array}{l}\text { First segment, pointed } \\
\text { medial process* }\end{array}$ & present & present & present \\
\hline \multicolumn{4}{|l|}{ Leg 5 free segment } \\
\hline Inner medial process & slender, acute tip & slender, blunt tip & broad, acute tip \\
\hline Inner apical spine length & 1.5 to outer spine & 1.0 to outer spine & 1.5 to outer spine \\
\hline
\end{tabular}

*main diagnostic character; **according to the figures.

as Kelleria sp.1, yet to be fully described, that appears to be endemic to Brazil. This pattern and the occurrence of two congener species of Kelleria in the same region reinforces Oomoto and Ueda (2016) statement, as quoted above.

\section{References}

CARDOSO, L.S. and MARQUES, D.M., 2004. Structure of the zooplankton community in a subtropical shallow lake (Itapeva Lake-South of Brazil) and its relationship to hydrodynamic aspects. Hydrobiologia, vol. 518, no. 1-3, pp. 123-134. http:// dx.doi.org/10.1023/B:HYDR.0000025062.08366.1b.

CHAGAS, G.G. and SUZUKI, M.S., 2005. Seasonal hydrochemical variation in a tropical coastal lagoon (Açu Lagoon, Brazil). Brazilian Journal of Biology = Revista Brasileira de Biologia, vol. 65, no. 4, pp. 597-607. http://dx.doi.org/10.1590/S151969842005000400006. PMid:16532183.

FUENTES-REINÉS, J.M. and SUÁREZ-MORALES, E., 2017. New records of poecilostomatoid copepods (Crustacea) from a coastal system in the Colombian Caribbean with notes on morphology. Check List, vol. 13, no. 5, pp. 513-523. http://dx.doi. org/10.15560/13.5.513.

GÓMEZ, S., 2006. Description of Kelleria reducta sp. nov.(Copepoda, Cyclopoida, Kelleriidae) from a brackish system in northwestern Mexico. Crustaceana, vol. 79, no. 7, pp. 879-892. http://dx.doi. org/10.1163/156854006778008203.

GURNEY, R., 1927. Report on the Crustacea: Copepoda (Littoral and Semi-parasitic). Transactions of the Zoological Society of London, vol. 22, no. 4, pp. 451-577. http://dx.doi. org/10.1111/j.1096-3642.1927.tb00207.x. 
HUMES, A.G. and HO, J.S., 1969. Cyclopoid copepods of the genus Kelleria (Lichomolgidae) from intertidal burrows in Madagascar. Bulletin of the British Museum (Natural History). Historical Series, vol. 18, pp. 221-229.

MONTEIRO, L.R. and GOMES-JUNIOR, J.L., 2005. Morphological divergence rate tests for natural selection: uncertainty of parameter estimation and robustness of results. Genetics and Molecular Biology, vol. 28, no. 2, pp. 345-355. http://dx.doi. org/10.1590/S1415-47572005000200028.

OOMOTO, M. and UEDA, H., 2016. Two new species of Kelleria (Copepoda, Poecilostomatoida, Kelleriidae) from Shikoku, Japan. Plankton E' Benthos Research, vol. 11, no. 2, pp. 37-48. http://dx.doi.org/10.3800/pbr.11.37.

PAPPAS, J.L. and STOERMER, E.F., 1996. Quantitative method for determining a representative algal sample count1. Journal of Phycology, vol. 32, no. 4, pp. 693-696. http://dx.doi.org/10.1111/ j.0022-3646.1996.00693.x.

ROCHA, G.M., FÉRES, J.C., ESTEVES, B.S. and STERZA, J.M., 2019. First record of the non-native copepod Pseudodiaptomus trihamatus Wright, 1937 (Copepoda, Calanoida) in Rio de Janeiro state, Brazil. Brazilian Journal of Biology $=$ Revista Brasileira de Biologia, vol. 79, no. 2, pp. 361-364. http://dx.doi.org/10.1590/15196984.183672. PMid:30066735.

ROCHA, G.M., FÉRES, J.C., BARCELOS-SILVA, P., STERZA, J.M. and FERNANDES, L.F.L., 2024. First record of Kelleridae in Brazilian waters. A geographical range expansion and a new Kelleria (Gurney, 1927) morphotype. Brazilian Journal of Biology = Revista Brasileira de Biologia, vol. 84, no. 54, e255748.

SUÁREZ-MORALES, E. and FUENTES-REINÉS, J.M., 2015. Registro de Kelleria reducta (Copepoda: Poecilostomatoida: Kelleriidae) en la costa caribeña de Colombia. Revista Mexicana de Biodiversidad, vol. 86, no. 1, pp. 28-33. http://dx.doi.org/10.7550/rmb.48345.

SUZUKI, M.S., FIGUEIREDO, R.O., CASTRO, S.C., SILVA, C.F., PEREIRA, E.A., SILVA, J.A. and ARAGON, G.T., 2002. Sand bar opening in a coastal lagoon (Iquipari) in the northern region of Rio de Janeiro State: hydrological and hydrochemical changes. Brazilian Journal of Biology = Revista Brasileira de Biologia, vol. 62, no. 1, pp. 51-62. http://dx.doi.org/10.1590/S1519-69842002000100007. PMid: 12185923.

WALTER, T.C. and BOXSHALL, G., 2021 [viewed 19 October 2021]. World of Copepods Database. Kelleria Gurney, 1927 [online]. World Register of Marine Species. Available from: http:// www.marinespecies.org/aphia.php?p=taxdetails\&id=205653 